\title{
Seks i męskość w wizerunkach gejów w wybranych tekstach popkultury
}

\author{
DOI: 10.19195/2083-7763.8.12
}

\section{Wstęp}

Niniejszy artykuł ma na celu przedstawienie w zarysie wyników badań własnych, dotyczących wizerunków homoseksualistów w amerykańskich fabułach obyczajowych. W opracowaniu skupiono się na ukazaniu sposobów ujmowania seksu i seksualności w tekstach popkultury w kontekście gejowskiej męskości. Analiza semiologiczna jako metoda badań umożliwiła odczytanie znaczeń konstruowanych w filmowych prezentacjach wokół seksualności homoseksualnych mężczyzn. Symbole i znaki budujące te kategorie mają udział w procesie społecznego konstruowania seksualności oraz są częścią publicznego dyskursu na temat homoseksualizmu, dlatego ich analiza z pewnością pozwala sięgnąć do symbolicznego uniwersum o szerokim zasięgu. Semiologiczna refleksja nad tematyką bezpośrednio dotykającą intymności, erotyki i tożsamości seksualnej jest zadaniem trudnym, ale warto podjąć to wyzwanie. Biorąc pod uwagę, jak ważna stała się komunikacja wizualna na przestrzeni ostatnich dekad, spoglądanie na nią pod kątem konstruowania aspektów tak bliskich sferze indentyfikacyjnej i aksjonormatywnej oraz prywatnej i publicznej zarazem wydaje się właściwą drogą. Proces analizy z pewnością daje sporo satysfakcji badaczowi, który ma szansę zajrzeć w głąb rzeczywistości społecznej, poznawać ją i rozumieć przede wszystkim poprzez język i obraz. Jest to próba zrozumienia, w jaki sposób jedna z najbardziej wymownych sfer komunikacji społecznej - popkultura - nadaje symboliczne znaczenia relacji między kategoriami seksu i tożsamości seksualnej gejów. To podróż po współczesności, w której seksualność i tożsamość płciowa wymagają stałego redefiniowania i rekonstruowania, co stawia wyzwania ideom ugruntowanym w tradycyjnym porządku symbolicznym. 
Fragmenty analiz przedstawionych w niniejszym artykule mają swoje źródło w wynikach badań, jakie zostały przeprowadzone w ramach projektów dwóch prac dyplomowych autorki - licencjackiej i magisterskiej. Podczas pierwszych wspomnianych badań zrealizowano case study amerykańskiego serialu Queer as Folk (USA, 2000-2005), opierając się na metodologii analizy semiologicznej i przyglądając się konstrukcjom męskości homoseksualnej w wizerunkach postaci. Wyboru tego właśnie tekstu popkultury dokonano ze względu na specyficzne i pionierskie w swoich czasach ujęcie tematu. Serial swoją wyjątkowość zawdzięcza fabule opartej na opowiadaniu losów homoseksualnych przyjaciół zmagających się z wyzwaniami rzeczywistości amerykańskiego Pittsburgha, która w sposób bezkompromisowy ukazała ich życie intymne oraz problemy codzienności, nieustanne dążenia za miłością, akceptacją, szczęściem i spełnieniem. W kolejnych analizach, również za pomocą narzędzi semiologii, kompleksowo przyglądano się prezentacjom wizerunków gejów i ich związków w antologii amerykańskiej kinematografii obyczajowej w latach 1980-2015. Oba przeprowadzone badania dotyczyły odkrywania znaków i symboli tworzących wyobrażenia, definicje i dyskursy wokół tożsamości seksualnej gejów. Miały one również na celu przeanalizowanie sposobów prezentacji kategorii opisujących symboliczny wymiar powiązania kwestii seksualności, płci oraz tożsamości społecznej. W niniejszym opracowaniu uwaga będzie skupiona na tej właśnie relacji, ze szczególnym uwzględnieniem sposobów ujęcia seksu i męskości w analizowanych wizerunkach gejów. Podjęta zostanie także próba przybliżenia sposobu funkcjonowania gejowskiego seksu jako popkulturowego mitu, czyli ugruntowanej kulturowo i językowo konstrukcji z zestawem wypracowanych, symbolicznie utrwalonych, znaczeń, obrazów i skojarzeń.

\section{Seks gejowski i popkultura}

Seks jako temat poruszany w popkulturze, zwłaszcza w kinematografii, doczekał się bardzo bogato obudowanej symboliki, przede wszystkim nawiązującej do heteroseksualnego romansu. Teksty popkultury, które trafiają do najliczniejszej publiczności, są pełne obrazów powstałych wokół mitologii miłości między kobietą a mężczyzną, w których seks jest właściwie jednym z najistotniejszych elementów znaczeniowych. W kulturze popularnej eksploracja seksu miewa wiele doniosłości funkcjonalnych. Socjologowie i badacze kultury dostrzegają jego istotną rolę w zakresie kreowania oraz utrwalania znaczeń i symboliki, przenikających świadomość społeczną na poziomie języka, przekonań, obrazów w pamięci, wyobrażeń i skojarzeń. Przyznają także, że popkulturowe prezentacje seksu mają moc legitymizacji pewnych norm i wzorców kulturowych dotyczących seksualności oraz wyznaczają ramy ich kategoryzacji. I właśnie owe ramy utrzymują status heteroseksualności nie tylko jako dominującej tożsamości seksualnej, lecz także, 
a nawet przed wszystkim, jako normy $\mathrm{w}$ istocie ${ }^{1}$. W rezultacie homoseksualny seks pozostaje właściwie poza granicami normy. Odzwierciedlenie dominacji heteronormy w popkulturze ujawnia się przede wszystkim w różnicach częstotliwości podejmowania tematu seksu hetero- i homoseksualnego, co jest dość oczywiste. Należy przy tym podkreślić, że ten drugi, znacznie rzadziej prezentowany na ekranie, nigdy nie doczekał się tylu reprezentacji i tak bogatej mitologii, jak erotyka $\mathrm{w}$ wydaniu damsko-męskim. To czyni ten temat szczególnie interesującym wyzwaniem dla socjologa poszukującego symbolicznych odniesień dla kategorii gejowskiej seksualności. Romans heteroseksualny, małżeństwo, monogamia i rodzina stanowią absolutne fundamenty amerykańskiej kultury seksualnej ${ }^{2}$, co nie wymaga dodatkowych potwierdzeń. Co w takim razie tworzy albo co ma potencjał tworzenia (sub)kultury seksualnej gejów? Niniejszy artykuł jest próbą odpowiedzi na to pytanie.

Seksualność homoseksualnego mężczyzny kategorycznie wykracza poza dominujące $\mathrm{w}$ popkulturze wzorce przedstawień. Istnieje niejako wbrew polityce seksualnej, która wokół gejowskiego seksu i homoseksualizmu w ogóle buduje atmosferę moralnej paniki, co znacznie wpływa na kształtowanie symbolicznych wyobrażeń dotyczących tego zjawiska. W wypadku budowania wizerunku mężczyzn homoseksualnych i ich relacji w popkulturze właściwie nie ma utrwalonego wzorca znaczeniowego i archetypów ról, które wciąż są w procesie tworzenia, co często staje się samo w sobie tematem fabuł filmowych. Popkulturowe wizerunki gejowskiego seksu w istocie stanowią binarną opozycję normatywną względem hetero, podobnie silną jak dychotomia między kobiecością i męskością, co wyraźnie zbliża to zjawisko do ram problematyki sfery aksjonormatywnej. Moralność i kwestie normatywne mają swój udział także w kształtowaniu wizerunków seksualności w popkulturze, których przemiany oddają dynamikę współczesności. Gary Sanders stwierdza jednoznacznie, że gejowskie relacje znajdują się w „tyranizującej triadzie znaczeń" - heteroseksizmu, homofobii i patriarchatu ${ }^{3}$. Jak podkreśla Samuel Nowak, proces tworzenia znaczeń wokół homoseksualizmu jest ciągłym konfliktem heteroseksualnych zasad i homoseksualnej niesubordynacji, który w popkulturze i sferze publicznej ujawnia się w strategiach reprezentacji i retoryki oraz kodach wizualnych ${ }^{4}$. Walka o uznanie i dominację toczy się też w ramach „wspólnot seksualnego smaku”, które konkurują z sobą i negocjują na arenie publicznego dyskursu ${ }^{5}$.

1 S. Seidman, Społeczne tworzenie seksualności, przeł. P. Tomanek, Warszawa 2012, s. 88.

2 Ibidem, s. 177.

3 G.L. Sanders, Men together: Working with gay couples in contemporary times, [w:] Couples on the Fault Line: New Directions for Therapists, red. P. Papp, Londyn-Nowy Jork 2000, s. 222-256.

${ }^{4}$ S. Nowak, Seksualny kapitat. Wyobrażone wspólnoty smaku i medialne tożsamości polskich gejów, Kraków 2013, s. 173-187.

${ }^{5}$ Ibidem, s. 173-187. 
Brian McNair w swojej książce zwrócił szczególną uwagę na to, w jaki sposób popkultura bierze udział $\mathrm{w}$ procesie seksualizacji kultury i demokratyzacji pożądania $^{6}$. W swoich rozważaniach nie pominął także sfery seksualności mężczyzn homoseksualnych. Wspomina, że metamorfozy społecznego postrzegania relacji gejowskich są ważnym symptomem zmiany świadomości społecznej oraz efektem oddziaływania mechanizmów tzw. kultury obnażania. To pojęcie wprowadza do opisu bezkompromisowości i bezpośredniości kulturowych w prezentacjach intymności i erotyki, zwłaszcza wizualnych ${ }^{7}$. Homoseksualni mężczyźni zyskali status „widoczności”, gdy odpowiednio zaczęły zmieniać się kreowane wokół nich znaczenia, w popkulturze i debacie publicznej zaczęto poszukiwać znaków do ich opisu, a status heteronormy nieco się rozluźnił ${ }^{8}$. Oczywiście omawiane kwestie, osadzone w sferze kultury popularnej, rozgrywały się na tle przemian o szerokim historycznym i społeczno-kulturowym zasięgu, które nie będą szczegółowo opisywane w niniejszym artykule, ponieważ ważne jest tu jedynie wskazanie pewnych trendów. Irlandzka socjolog Aoife Neary zauważa ową wielość kontekstów postrzegania i budowania relacji homoseksualnej, w tym jej wymiaru seksualnego ${ }^{9}$. Są to konteksty między innymi regulacji prawnych, norm społecznych, wzorów kulturowych, z czego szczególnie interesujący jest ten ostatni. W nim bowiem mieszczą się analizy badawcze oraz refleksje zawarte w niniejszym opracowaniu. Bardzo istotnym aspektem obudowywania seksualności gejów znaczeniami jest to, że właściwie życie codzienne par homoseksualnych to ciągłe zmaganie się z egzystencją w heteronormatywnej rzeczywistości. Neary wykazuje, że binarna opozycja między kategoriami powstaje już na poziomie określeń relacji związek partnerski-małżeństwo ${ }^{10}$. Symboliczna różnica na zasadzie przeciwieństwa jednoznacznie ukierunkowuje społeczne wyobrażania $\mathrm{w}$ ich kategoryzowaniu i hierarchizuje binarnie przypisywane im wartości według poziomu dominacji.

Wyniki badań jednoznacznie obalają wiele mitów wytworzonych w procesie budowania znaczeń na temat seksualności gejów, ten, który głosi, że seks odgrywa dla tych par kluczową rolę. Natomiast cele, jakie chcą osiągać partnerzy, są w istocie współmierne do tych, na które wskazują także pary heteroseksualne ${ }^{11}$. Warto wspomnieć również o wynikach nowozelandzkich badań zrealizowanych w grupie gejów w latach dziewięćdziesiątych (okres uwidaczniania i budowania

${ }^{6}$ B. McNair, Seks, demokratyzacja pożądania i media, czyli kultura obnażania, przeł. E. Klekot, Warszawa 2004.

7 Ibidem.

8 Ibidem, s. 255.

9 A. Neary, Same-sex relationship recognition and the weight of heteronormative expectation, „Socheolas" 4, 2012, nr 1.

10 Ibidem.

11 L.A. Peplau, Research on homosexual couples: an overwiev, „Journal of Homosexuality" 8, 1982, nr 1. 
gejowskiej tożsamości w sferze publicznej), które potwierdzają, iż w relacji między mężczyznami całkiem dobrze ma się wzorzec heteroseksualnej miłości romantycznej oraz heteronormatywnej męskości ${ }^{12}$. Świadczy to o ogromnej sile, która tkwi w budowaniu znaczeń na zasadzie odniesienia, co ciekawe - do konstrukcji binarnie opozycyjnej, jaką jest ideał heteroseksualnego romansu. Okazuje się, że sfera negocjacji, kreowania i utrwalania znaczeń wokół seksualnej tożsamości homoseksualnych mężczyzn znajduje się właściwie na styku między innymi codzienności, oczekiwań społecznych, odniesień kulturowych i normatywnych, co czyni ten obszar szczególnie interesującym dla badacza, a sam proces poznawczy - ogromnym wyzwaniem.

\section{Poszukiwania źródeł mitologii gejowskiej seksualności}

Pierwszy projekt badawczy, realizowany $\mathrm{w}$ trakcie powstawania pracy licencjackiej, nie tylko stał się inspiracją do dalszych dociekań, lecz przede wszystkim, co ważne dla tematu podejmowanego w niniejszym artykule, pozwolił odkryć symboliczną doniosłość prezentacji seksualności gejowskiej na ekranie. Analiza znaczeń i symboli w wizerunkach gejów odkrywanych w case study serialu amerykańskiego Queer as Folk była impulsem do namysłu nad kategoriami homoseksualnej tożsamości społeczno-kulturowej, w tym przede wszystkim intymności i tożsamości seksualnej. W badaniach przeprowadzonych w ramach pracy magisterskiej analizie semiologicznej zostały poddane jednostki dobrane według próby celowej, składającej się z wyselekcjonowanych wizerunków par homoseksualnych mężczyzn, wyróżnionych spośród dwunastu źródeł filmowych. Pod uwagę brane były filmy o największym udziale producenckim Stanów Zjednoczonych, realizujące jak najwięcej cech gatunkowych kina obyczajowego, o mainstreamowym, globalnym charakterze dystrybucji. W wybranych filmach postaci homoseksualnych mężczyzn i wątek ich relacji musiały być pierwszoplanowe.

W zasadzie obserwacje i interpretacje, które były rezultatem projektów dyplomowych, pozwoliły wypracować schemat odkodowywania treści, który w miarę możliwości unika nadinterpretacji i otwiera się na intersubiektywność, odkrywając wciąż nowe wymiary gejowskiej tożsamości w popkulturze. Sposób spojrzenia na prezentacje seksualności w treściach filmowych jest podyktowany potrzebą szczegółowego, rzetelnego opracowania oraz ujęcia go w symboliczne ramy poszukiwania wyznaczników barthesowskiej „mitologii”"13 gejowskiej tożsamości. Do skonstruowania narzędzia badawczego analizy semiologicznej posłużył wykaz cech znaku postaci ludzkiego ciała autorstwa Gillian Dyer, na którą

${ }^{12} \mathrm{H}$. Worth, A. Reid, K. McMillan, Somewhere over the rainbow: love, trust and monogamy in gay relationships, „Journal of Sociology” 38, 2002, nr 3.

13 R. Barthes, Mitologie, przeł. A. Dziadek, Warszawa 2000. 
w swojej publikacji powołuje się Gillian Rose ${ }^{14}$. W procesie szczegółowego opisywania cech postaci wykorzystany został także podstawowy podział analityczny G. Rose na modalność kompozycyjną (wizualnie dostrzegalne elementy zewnętrznych wizerunków portretów postaci) oraz modalność społeczną obrazu ${ }^{15}$ (praktyki społeczne w obrębie kreacji bohaterów). Narzędzie badawcze w wypadku obu analiz zawierało zbiór kategorii opisu charakterystyk filmowych kreacji homoseksualnych mężczyzn i ich relacji selekcjonowanych według dwóch modalności. Narzędzia różniły się od siebie, ponieważ w trakcie drugiego projektu dyplomowego, z użyciem tej samej metodologii, zakres analizy poszerzony został o charakterystykę i interpretację symbolicznego wymiaru relacji między homoseksualnymi bohaterami głównego wątku. W tabelach zamieszczono oba narzędzia badawcze, które posłużyły do usystematyzowania analizy semiologicznej znaczeń ukutych wokół kategorii homoseksualnych mężczyzn w popularnych amerykańskich filmach i serialu. Elementy, które uwzględniają schematy analityczne, rekonstruują zarówno strukturę kompozycji wizualnych cech postaci, jak $\mathrm{i}$ ich funkcjonowanie w przedstawionym $\mathrm{w}$ fabule świecie społecznym.

Tabela 1. Narzędzie badawcze w projekcie pracy licencjackiej

\begin{tabular}{|c|c|}
\hline Wymiar kompozycyjny & Wymiar społeczny \\
\hline $\begin{array}{l}\text { Przedstawienie ciała: } \\
\text { — wiek (w jakim wieku jest postać?) } \\
\text { — włosy (kolor i fryzura) } \\
\text { — ciało (typ sylwetki, szczególnie eksponowane } \\
\text { części ciała) } \\
\text { — wygląd twarzy (kształt twarzy, znaki szczególne) } \\
\text { — ubiór (typowy dla postaci styl ubierania się i jego } \\
\text { modyfikacje) }\end{array}$ & $\begin{array}{l}\text { Wymiary działań i relacji społecznych: } \\
\text { — praca } \\
\text { — rodzina } \\
\text { — przyjaciele i znajomi } \\
\text { — związki } \\
\text { — uzdolnienia, zainteresowania i hobby } \\
\text { — rozrywki } \\
\text { — inna szczególna działalność } \\
\text { i przełomowe wydarzenia dla danej postaci }\end{array}$ \\
\hline $\begin{array}{l}\text { Zachowanie: } \\
\text { — ekspresja (typowy dla danej postaci sposób } \\
\text { wyrażania emocji uwidoczniony na twarzy; } \\
\text { typowe środki ekspresji w mimice) } \\
\text { — postawy ciała (gesty, pozy i ruchy ciała } \\
\text { typowe dla postaci, sposób wykorzystywania dotyku } \\
\text { w obrębie ciała) }\end{array}$ & $\begin{array}{l}\text { Położenie społeczne: } \\
\text { — miejsca przebywania i otoczenie społeczne } \\
\text { — status społeczny i materialny }\end{array}$ \\
\hline $\begin{array}{l}\text { Rekwizyty i scenografia: } \\
\text { — rekwizyty (atrybuty postaci i przedmioty } \\
\text { o szczególnym dla niej znaczeniu) } \\
\text { — scenografia (aranżacja otoczenia, w którym } \\
\text { najczęściej pojawia się dana postać) }\end{array}$ & $\begin{array}{l}\text { Cytaty komentujące postać: } \\
\text { — wypowiedzi komentujące wizerunek postaci } \\
\text { — wypowiedzi komentujące osobowość postaci } \\
\text { — wypowiedzi postaci o samej sobie }\end{array}$ \\
\hline
\end{tabular}

Źródło: opracowanie własne.

14 G. Rose, Interpretacja materiałów wizualnych. Krytyczna metodologia badań nad wizualnościa, przeł. E. Klekot, Warszawa 2010, s. 109.

${ }^{15}$ Ibidem, s. 33. 
Tabela 2. Narzędzie badawcze w projekcie pracy magisterskiej

\begin{tabular}{|c|c|}
\hline Wymiar kompozycyjny & Wymiar społeczny \\
\hline $\begin{array}{l}\text { Przedstawienie ciała: } \\
\text { — wiek (w jakim wieku jest postać?) } \\
\text { — wygląd ciała (sylwetka, twarz, znaki szczególne) } \\
\text { — ubiór (typowy dla postaci styl ubierania się i jego } \\
\text { modyfikacje) }\end{array}$ & $\begin{array}{l}\text { Wymiary działań i relacji społecznych: } \\
\text { — praca } \\
\text { — rodzina } \\
\text { — przyjaciele i znajomi } \\
\text { — uzdolnienia, zainteresowania i hobby, rozrywki } \\
\text { — inna szczególna działalność } \\
\text { i przełomowe wydarzenia dla danej postaci }\end{array}$ \\
\hline $\begin{array}{l}\text { Zachowanie: } \\
\text { — ekspresja (typowy dla danej postaci sposób } \\
\text { wyrażania emocji uwidoczniony na twarzy; } \\
\text { typowe środki ekspresji w mimice) } \\
\text { — postawy ciała (gesty, pozy i ruchy ciała } \\
\text { typowe dla postaci, sposób wykorzystywania dotyku } \\
\text { w obrębie ciała) }\end{array}$ & $\begin{array}{l}\text { Położenie społeczne: } \\
\text { — miejsca przebywania i otoczenie społeczne } \\
\text { — status społeczny i materialny }\end{array}$ \\
\hline $\begin{array}{l}\text { Rekwizyty i scenografia: } \\
\text { — rekwizyty (atrybuty postaci i przedmioty } \\
\text { o szczególnym dla niej znaczeniu) } \\
\text { — scenografia (aranżacja otoczenia, w którym } \\
\text { najczęściej pojawia się postać) }\end{array}$ & $\begin{array}{l}\text { Historia relacji z partnerem (kategoria wspólna dla } \\
\text { opisu obu postaci) } \\
\text { — zapoznanie się i pierwsze spotkanie } \\
\text { — zawiązanie bliskiej relacji } \\
\text { — miejsca i charakter spotkań } \\
\text { — najważniejsze wydarzenia podczas trwania relacji } \\
\text { — charakter i typ związku } \\
\text { — podział ról w relacji } \\
\text { — fizyczność i stosunki seksualne w relacji } \\
\text { — cenione wartości w związku } \\
\text { — język opisu relacji } \\
\text { — subiektywna ocena relacji przez postać } \\
\text { — postrzeganie relacji przez otoczenie społeczne } \\
\text { (rodzina, znajomi, wspótpracownicy, sąsiedzi) } \\
\text { — oceny relacji przez otoczenie społeczne }\end{array}$ \\
\hline
\end{tabular}

Źródło: opracowanie własne.

Warto wspomnieć, że bardzo ważną decyzją w obu projektach badawczych było ukierunkowanie kontekstu analizy na kinematografię amerykańską, co jest podyktowane rezultatami dociekań teoretycznych i uznanym przez teoretyków seksualności i popkultury stwierdzeniem, iż droga do "globalnego” wiedzie przez „amerykańskie"16. Najważniejsze w drodze do osiągnięcia celu badań było wydobycie przemian w kształtowaniu symbolicznych mitów wokół tożsamości homoseksualnych mężczyzn, natomiast w niniejszym artykule kluczową kwestią będzie uchwycenie metamorfoz w aspekcie seksu i seksualności gejów.

16 Por. S. Seidman, op. cit.; B. McNair, op. cit. 


\section{Seksualność gejów — od wstydu do dumy?}

W analizowanych treściach fabularnych tożsamość seksualna ujawniła się faktycznie jako jeden z centralnych czynników analitycznych, natomiast sama problematyka seksualności w wymiarze erotyki, intymności i aktu seksualnego okazała się głównie środkiem wyrazu służącym prezentacji konwencji. Biorąc pod uwagę to, że wybrane obrazy filmowe są z założenia popularne i pochodzą z tzw. głównego nurtu, erotyka jako środek przekazu bywa tu stosowana w sposób dość ostrożny, z użyciem wielu kinowych eufemizmów i aluzji. Nie jest to jednak reguła, co również stanowi pewien klucz analityczny. Dokonując przeglądu wyników badań w poszukiwaniu wyznaczników symbolicznych relacji między męskością, homoseksualizmem i seksem, starano się również zwrócić uwagę na to, w jaki sposób ulegały one przemianom oraz jakie kierunki trendów kreują owe przemiany. Zostaną one przedstawione zgodnie z podziałem analitycznym na cztery przedziały czasowe: lata osiemdziesiąte (obejmujące okres od 1980 do 1989 roku), lata dziewięćdziesiąte (okres od 1990 do 1999 roku), pierwsza dekada XXI wieku (okres od 2000 do 2010 roku) oraz początek drugiej dekady XXI wieku (okres od 2011 do 2014 roku).

Tożsamość seksualna jest zjawiskiem zarówno kulturowym, jak i historycznym oraz społecznym, silnie osadzonym we wszystkich tych kontekstach, i tak też powinna być analizowana przez badaczy ${ }^{17}$. Warto zatem wspomnieć w paru słowach o roli tych kontekstów w analizie autorki niniejszego artykułu. Lata pięćdziesiąte i sześćdziesiąte ubiegłego wieku to, zwłaszcza w Stanach Zjednoczonych, okres powstawania i rozwoju kontrkultury oraz jednocześnie prób symbolicznej walki z nadchodzącymi zmianami poprzez umacnianie społecznej kontroli seksualności. Owe dekady zaowocowały zasadniczymi zmianami w postrzeganiu seksu i seksualności, które stworzyły podwaliny pod późniejszy kształt społeczno-kulturowych symboli wokół tożsamości seksualnych, ale oczywiście nie zapisały wielu tytułów w antologii mainstreamowych filmów z wątkami homoseksualnymi na pierwszym planie.

Lata siedemdziesiąte były fundamentem, który poprzez stopniowe wprowadzanie do mainstreamu wizerunków „dzieci” seksualnej rewolucji przygotował grunt pod kolejne ewolucje. Wtedy też, między innymi dzięki pionierskim aktywnościom ruchów gejów i lesbijek, zaczęto rozpowszechniać postrzeganie homoseksualności jako pozytywnej tożsamości społecznej. W drugiej połowie tej dekady w mediach amerykańskich temat homoseksualizmu pojawiał się coraz częściej, jednak filmy, w których można był odnaleźć homoseksualne reprezentacje, były mniej popularne i umieszczały postaci gejów na dalszych planach.

Dopiero lata osiemdziesiąte są pierwszym okresem, w którym w antologii kinematografii mainstreamowej faktycznie można odnaleźć pierwszoplanowe przed-

17 S. Seidman, op. cit. 
stawienia relacji między dwoma mężczyznami. W owej dekadzie postaci homoseksualnych mężczyzn stopniowo coraz częściej zaczęły pojawiać się w filmach kinowych oraz w produkcjach telewizyjnych. W tym przedziale czasowym po raz pierwszy pojawiły się symboliczne konteksty, które ukształtowały utrwalone wyobrażenia na temat ukazywania gejów w kinie. W filmach $\mathrm{z}$ lat osiemdziesiątych tożsamość gejowska sama w sobie była prezentowana jako problematyczna, stanowiła właściwie oś dramaturgii losów bohaterów. Seksualność natomiast była wyraźnie portretowana jako problem, ale nie tylko w skali obejmującej perypetie homoseksualnych postaci, lecz także, a raczej przede wszystkim, w szerokiej skali oddziaływania społecznego. Wyobraźnię zdominowały w tym czasie relacje między homoseksualizmem a paniką społeczną wokół epidemii AIDS, która na dobre zagościła w świadomości wielu jako bezpośredni efekt gejowskiej rozwiązłości seksualnej. Dla tego okresu problem rozprzestrzeniania się wirusa HIV i zwiększenia zachorowań na AIDS w środowiskach gejowskich okazał się znamienny. W amerykańskim kinie obyczajowym stosowano zabiegi osadzania postaci w dramatycznych okolicznościach, w obliczu śmiertelnej choroby, która w tamtej dekadzie faktycznie była problemem amerykańskiego społeczeństwa.

Dwa z trzech wybranych z tej dekady filmów bardzo wyraźnie zaprezentowały w fabule ten temat (Parting Glances 1986, Longtime Companion 1989). W pierwszym z nich choruje ekscentryczny i nieco egoistyczny były kochanek i zarazem przyjaciel jednego $\mathrm{z}$ partnerów gejowskiego związku. $\mathrm{W}$ drugim natomiast ukazano kilka lat z życia grupy przyjaźniących się mężczyzn w obliczu dramatu choroby i śmierci. Ewidentnie mamy tu do czynienia z prezentacją seksu gejowskiego jako przyczyny rozprzestrzeniania choroby, a zatem również strachu, lęku, cierpienia, śmierci. Nie jest to obrazowane wprost, ale zostało wyartykułowane symbolicznie, implicite, zawarte w wyeksponowanych emocjach i przeżyciach wewnętrznych bohaterów. Ważne, aby nie zrozumieć tego opacznie - filmy w warstwie fabularnej nie zawierały negatywnej oceny homoseksualizmu, ale w warstwie znaczeniowej ukazywały bardzo dobitnie powiązanie tożsamości gejowskiej i AIDS jako problem społeczny — problem, w którym gejowska seksualność ma swój niechlubny udział. Jest to również sedno dramaturgii homoseksualnych mężczyzn. Choroba faktycznie staje się znakiem bólu, cierpienia, braku nadziei i rozstania.

Scen ukazujących seksualne zbliżenia w wybranych filmach praktycznie nie zaobserwowano. Można było zauważyć za to wiele zabiegów służących ominięciu tematu poprzez woalowanie i kadrowanie scen, ograniczanie ich do odrobiny nagości i pozostawienie dalszego ciągu sugestii i domysłowi. Seksualność gejów kina lat osiemdziesiątych to seksualność outsiderów. Bardzo wyraźnie widać to również w filmie Making love z 1982 roku, który pomija temat AIDS i skupia się na przedstawieniu dramatu niespełnionego uczucia rozgrywającego się między dwoma mężczyznami na tle pozornie szczęśliwego małżeństwa jednego z nich. Relacja między bohaterami podkreśla symbolikę sekretnego, zakazanego, niespełnionego i ulotnego romansu. Dodatkowo reprezentują oni dwa zupełnie 
odmienne światy społeczne, co jest niezwykle symboliczne: świat tradycyjnego ładu uporządkowanej moralnie seksualności, małżeństwa i monogamii oraz świat gejowski, pełen swobody seksualnej, rozwiązłości, a także luksusowego stylu życia. Pragnienie uczucia i fizycznego zbliżenia zderzają się z rzeczywistością, która nie chce akceptować i być przychylną homoseksualnym relacjom oraz czyni je zakazaną przyjemnością. Symbolicznie je odrzuca, pozostawiając niepokój, pustkę i cierpienie po obu stronach seksualnego, społeczno-kulturowego (nie)porząaku. Seksualność gejowska jako centralna kategoria w fabułach filmowych była zjawiskiem piętrzącym trudności, osadzonym w samym centrum dramaturgii wynikającej z problemów śmiertelnej choroby, moralnego chaosu, braku akceptacji społecznej i rozpadu rodziny.

Lata dziewięćdziesiąte to czas, w którym bycie gejem w zachodniej, a przede wszystkim amerykańskiej, kulturze, jak pisze Brian $\mathrm{McNair}^{18}$, stało się „cool”. W kinematografii seksualność była wtedy głównym wyznacznikiem tożsamości, aczkolwiek tuż obok trendu jej fabularnej centralizacji w filmach pojawiają się też pierwsze nawiązania queerowe (The Living End 1992). Obrazy kinowe poruszające tematykę związków gejowskich zyskują nowe konotacje gatunkowe. Bohaterowie coraz częściej są osadzani w typowych fabułach romantycznych oraz komediowych, które tracą melodramatyczną wymowę, jaka święciła triumfy w poprzedniej dekadzie. Nadal wybrzmiewa problem AIDS, ale nie jest już motywem przewodnim przy prezentacji homoseksualnych postaci. Lata dziewięćdziesiąte stają się przełomowe dla popularyzacji samej tematyki. Gdy Tom Hanks, odtwórca głównej roli w dramacie Philadelphia (1994), zdobywa Oscara, wiadomo już, że film zyska status przełomowego, wręcz kultowego w swoim gatunku oraz pod względem prezentacji tematu. Obraz przede wszystkim jako pierwszy łączy wątek homoseksualny bohaterów osadzonych wysoko w hierarchii społecznej oraz problem AIDS i implementuje go do globalnej świadomości społecznej widzów kina popularnego. W tym filmie, a także w omawianej w badaniach komedii Trick (1999) po raz pierwszy tak wyraźnie pojawiają się konwencje romansu heteroseksualnego, $\mathrm{z}$ wpisanym w niego wzorem romantycznej miłości i pragnieniem monogamicznej, trwałej relacji, z seksem jako dopełnieniem miłosnej całości. W Philadelphii, trzymając się poprawności politycznej, zupełnie zrezygnowano z prezentacji aktów fizycznych między mężczyznami, kładąc nacisk na ukazanie problemu marginalizowanej tożsamości seksualnej oraz AIDS poprzez budowanie wielowątkowej dramaturgii i stopniowe rozkładanie emocji. Natomiast w Trick zaczęły pojawiać się pierwsze, bardziej odważne w wymowie sceny aktów seksualnych. Nadal są specyficznie wykadrowane i niekompletne, jednak wyraźnie zaznaczają symboliczny wymiar prezentacji męskiego, pięknego ciała. W filmie The Living End, pełnym subtelnych symbolicznie, queerowych motywów, seks jest brudny i niezwykle wymowny, choć w kadrach uwidacznia się

18 Por. B. McNair, op. cit., s. 255. 
właściwie jedynie mimika twarzy bohaterów. Znamienna jest końcowa scena, gdy jeden $\mathrm{z}$ bohaterów związuje drugiego, zmuszając do stosunku seksualnego i przystawiając sobie pistolet do ust. W fabułach pojawiają się także pierwsze symptomy budowania znaczeń wokół gejowskiej (sub)kultury seksualnej poprzez zbliżenia na darkroomy, kluby i sceny erotycznego tańca półnagich męskich ciał.

Geje z filmów lat dziewięćdziesiątych są klientami „oaz” seksualnych przyjemności, często nawiązują czysto fizyczne, krótkotrwałe i jednorazowe relacje z mężczyznami. Jednak, co najbardziej znaczące, szczególnie zapadającym w pamięć i przełomowym dla tej dekady pozostanie długotrwały i stabilny związek partnerski ukazany w Philadelphii bez cienia seksualnych nawiązań, poza odwołaniem do napiętnowania AIDS, przenoszonego drogą płciową, które zrobiło karierę już w poprzedniej dekadzie. Seks przestał być zakazaną przyjemnością, a stał się trudnym do realizacji, niebezpiecznym i nieco brudnym pragnieniem, które w ogólnym rozrachunku blednie przy dążeniach do równowagi emocjonalnej i monogamicznej, romantycznej stabilizacji.

Okres dziesięciolecia tuż po przełomie wieku XX i XXI to czas pierwszych symbolicznych przełomów w mitologii wizerunków gejowskiej seksualności zawierającej utrwalone znaczenia szerokiego zasięgu. Zabiegi stosowane w fabułach pojawiają sie do dziś jako trwałe symboliczne konteksty, a powstałe wtedy filmy i seriale zyskały status kultowych w swoim gatunku (serial Queer as Folk, film Tajemnica Brokeback Mountain). Trend decentralizacji i dekonstrukcji tożsamości seksualnej, który zaznaczył się nieśmiało w poprzedniej dekadzie, ustąpił powrotom do koncepcji centralizacji seksualności gejów jako głównej osi dramaturgii ich losów. Jednocześnie postawiono na strategię normalizacji seksualnej tożsamości, starając się przedstawiać homoseksualnych mężczyzn jako pragnących odnaleźć się w symbolicznym porządku na zasadach heteroseksualnego romansu. Doskonale jest to widoczne w Tajemnicy Brokeback Mountain, gdzie seks staje się prawdziwym źródłem bólu i cierpienia bohaterów, którzy poprzez nie oddalają się symbolicznie od porządku sztywnych regulacji płci i zachowań seksualnych, jakie w czasach akcji filmu, czyli w latach sześćdziesiątych, stanowiły ramy moralności społecznej Amerykanów. Seks jest przyczyną wewnętrznych rozterek postaci i ich życiowych dramatów: rozpadu więzi społecznych, problemów tożsamościowych, tęsknoty i nieszczęśliwej miłości. Uwydatniono tu namiętne i pełne emocji kontakty seksualne pokazane w całości, wręcz naturalistycznie, jedynie bez genitalnych szczegółów. Mężczyźni dotykają się i całują, jednak jest to okupione sprzecznymi, silnymi emocjami gniewu i bezsilności, co bardzo podkreśla symboliczną walkę cielesnych pragnień z uświadamianymi ograniczeniami.

Film Shelter (2007) jest hołdem dla konwencji normalizacji seksualności, podkreślającym źródło inspiracji w heteroseksualnym romansie, w którym czuły i namiętny kontakt fizyczny daje partnerom przede wszystkim satysfakcję, radość i spełnienie oraz bliskość i poczucie bycia kochanym i akceptowanym. To homoseksualny romans, który ogląda się z podobną przyjemnością i wrażeniami, jakie towarzyszą 
śledzeniu losów heteroseksualnych zakochanych, z tą różnicą, że w Shelter przeszkodę dla kochanków stanowi problem akceptacji seksualnej tożsamości.

Z kolei I Love Sou, Phillip Morris z 2009 roku pokazuje podobny trend, obudowując go komediową konwencją, pół żartem, pół serio kryminalną, z więzieniem i malwersacjami finansowymi w tle. Bohaterowie odnajdują w zbliżeniu seksualnym siebie, spełnienie swoich pragnień o szczęściu i przyjemności połączonej z prawdziwą miłością. W obu przypadkach zwycięża seks podany widzom "na tacy” wraz z romantyczną miłością, co pozwala wprowadzić i ugruntować trend normalizacji, jaki zagościł na dobre w mainstreamowych przedstawieniach relacji homoseksualnych. Realizuje go częściowo również serialowa opowieść Queer as Folk (2000-2005), którą poddano analizie w ramach case study, jednak jest to historia w gruncie rzeczy dużo bardziej złożona. Serial niezwykle zgrabnie łączy wszystkie konwencje, tworząc bardzo „smaczną” dla widzów całość, wprowadzając wątki queerowe jako atrakcyjne w odbiorze dla publiczności zarówno homo, jak i heteroseksualnej. Prezentacje bezkompromisowych, szczegółowo ukazanych i bardzo atrakcyjnych wizualnie scen aktów seksualnych - monogamicznych oraz z wykorzystaniem różnych konfiguracji (wraz z fetyszami, hiperseksualnością i dozą brutalności w tle, w towarzystwie romantycznych, chwytających za serce symbolicznych opisów czułości, uczuciowości i miłości) - stworzyły zupełnie nową jakość. Dodatkowo piękne, męskie ciała, pełne seksualnego wigoru, apetyczne dla oka potęgują wrażenie doświadczania czegoś nowego, niezwykłego. Uznany za kultowy i popularyzowany na całym świecie serial okazał się dla widzów wartościowy także w swojej symbolicznej wymowie, która została wyeksponowana już w tytule jako dostrzeżenie w homoseksualnych mężczyznach ludzi pragnących miłości, akceptacji i szczęścia, podobnych w gruncie rzeczy do heteroseksualnych bohaterów (queer as folk, czyli „dziwny” lub „pedał” jak człowiek). Fabuła eksponuje również specyfikę środowiska społecznego wielkomiejskich gejów, która symbolicznie odnosi się do seksualności, budując znaczenia wokół rozwiązłości, fetyszy i seksu jako czystej przyjemności na zasadzie sprzeczności i konwencji humorystycznej. W serialu możemy zobaczyć zbliżenia na wnętrza klubów, łaźni, darkroomów, w których zabawy seksem i symboliczne igraszki z płcią są na porządku dziennym. Ten queerowy manifest osadzony w konwencji romantycznej staje się akceptowalny dla popularnej publiczności i dzięki temu połączeniu stworzył nową jakość w ujęciu tematyki seksualności gejowskiej, pozostającej w sprzeczności i wciąż w symbolicznym procesie budowania. Jest to niezwykle inspirujące, szczególnie do dalszych dociekań badawczych, mających za zadanie rekonstruować ten proces.

Ostatni okres, któremu przyglądano się pod kątem obrazowania wizerunków homoseksualnych mężczyzn i ich seksualnej tożsamości, to czas między 2010 a 2015 rokiem, gdy dokonano podsumowania analiz w ramach projektu dyplomowego. W tym przedziale czasowym po raz pierwszy wyraźnie dokonano pewnego odciążenia z piętna gejowskiej seksualności jako wykluczonej i problematycznej samej w sobie. Tożsamość homoseksualnych mężczyzn zostaje ostatecznie 
zdecentralizowana. Seks dla par zaprezentowanych w filmach jest przede wszystkim środkiem wyrazu emocji, w fabule zaś pełni funkcję symbolicznego dopełnienia opowieści oraz narzędzia komunikacji wizerunku postaci. Bywa także, podobnie jak w serialu Queer as Folk, elementem kluczowym, lecz zazwyczaj w kwestii ustalenia reguł relacji między mężczyznami, nie wprowadzania dramaturgii. Filmy August (2011) oraz Keep The Lights On (2012) poruszające wątki zdrady, uzależnienia od narkotyków i emocjonalnego zagubienia bohaterów pokazują właściwie symboliczną, wewnętrzną walkę o monogamię, oddanie i romantyczną wyłączność partnerów w relacji. Oba filmy, podobne do siebie w wymowie i tematyce, używają seksu jako narzędzia do budowania napięcia między bohaterami, ukazania atmosfery dramaturgii, w której najważniejsze staje się emocjonalne uwikłanie postaci. Motyw nieszczęśliwej miłości pojawia się jako efekt pewnego niedopasowania partnerów na wielu polach, natomiast seks sam w sobie jest jedynie środkiem do realizacji pragnień, okazywania uczuć i łagodzenia frustracji. Oto jeden z symbolicznych wymiarów zabiegu decentralizacji tożsamości seksualnej gejów w kinie. Ów zabieg okazał się mieć także inne konsekwencje. Między innymi dzięki niemu nastąpił przełom, który rozszerzył granice portretowania postaci gejów i ich seksualnej tożsamości. Zaczęto bowiem prezentować homoseksualnych mężczyzn również w starszym wieku, tak jak w filmie Love Is Strange z 2014 roku. Co ciekawe, jako jeden $\mathrm{z}$ pionierskich obrazów poruszających tę tematykę $\mathrm{w}$ takim kontekście, film unika prezentacji seksualności bohaterów. Zamiast tego wkłada ją w ramy heteroseksualnego wzoru czułości, romantyzmu i trwałego, monogamicznego związku, rezygnując ze zbliżeń na życie seksualne starszych mężczyzn, co ma swoje konsekwencje. Przede wszystkim wyznacza symboliczne granice popkulturowych ujęć cielesności i seksualności gejów oraz kierunek i tempo ich rozszerzania.

Reprezentacje filmowe seksualności homoseksualnych mężczyzn przeszły prawdziwą drogę od symbolicznej niewidoczności do widoczności, wytyczonej przez kulturowe ramy w kontekście zmiany społecznej ${ }^{19}$. Lata osiemdziesiąte i dziewięćdziesiąte ograniczały prezentowanie seksu jedynie do dotyku i pocałunków, dokonując fragmentacji i kadrowania scen aktów seksualnych, które pozostały niedopowiedziane, niejednoznaczne. Seks gejów, symbolicznie zawoalowany i jednocześnie centralizowany w dramaturgii, był „zakazany”, niewłaściwy, piętrzył trudności w relacji między mężczyznami oraz pośrednio był przyczyną cierpienia związanego z AIDS. Okres po roku 2000 i późniejsze lata powoli przygotowywały grunt pod decentralizację tożsamości seksualnej w wizerunkach homoseksualnych mężczyzn. Seks stał się kluczowym elementem rozwoju więzi między bohaterami, był coraz śmielej obrazowany. Współcześnie dominuje wręcz naturalizm w przedstawieniach aktów seksualnych, w trakcie ich realizacji kamera jest bardzo blisko. Podczas tych scen częstym zabiegiem jest także przedstawianie męskich ciał poddanych fragmentaryzacji na potrzeby uwypuklenia symboli i emocji.

19 S.D. Walters, All The Rage: The Story of Gay Visibility in America, Chicago 2003, s. 9-10. 


\section{Podsumowanie}

Symboliczny wymiar reprezentacji seksualności gejów w popkulturze okazał się szczególnie ciekawym, fascynującym obszarem dociekań badawczych. Mitologie spajające kategorie seksu, męskości i homoseksualizmu w prezentacjach fabularnych zdecydowanie wyznaczają kierunki procesu kreowania tożsamości seksualnej w sferze popkulturowych znaczeń. Jest to proces otwarty, w trakcie budowania, dlatego stanowi tak interesujący temat socjologicznej i kulturowej analizy.

Praca analityczna wykazała, iż seks gejów w wybranych fabułach był udziałem przede wszystkim zawsze pięknych i młodych mężczyzn. Zwracano uwagę na ukazywanie pięknej, atrakcyjnej cielesności, zaniechano natomiast prezentacji seksu mężczyzn starszych, niepełnosprawnych, niepasujących do kulturowych wzorców estetyki męskiego ciała. Filmowi i serialowi geje uprawiali bardzo dużo seksu, wiele innych ich aktywności pośrednio wiązano z seksem, tak jak spędzanie wolnego czasu, rozrywkę, uzyskiwanie korzyści w pracy. Jednocześnie homoseksualni mężczyźni poprzez seks ujawniali ukrytą lub jawną uczuciowość, emocjonalność i zaangażowanie, co jest nawiązaniem do modelu "nowej męskości” oraz wprowadzeniem pewnej dozy pierwiastka kobiecego, aby ukazać, że podział ról w związku jest podobny do tego, jaki występuje w heteroseksualnym romansie. Seks gejowski ma w istocie dwa wymiary, opozycyjne wobec siebie. Z jednej strony romantyczny seks między mężczyznami jest czysty, dopuszczalny, „z miłości”, intymny, a jego miejsce to sypialnia, wspólne łoże kochanków. $Z$ drugiej strony bywa brudny, przygodny, związany z niebezpiecznymi konsekwencjami i zazwyczaj ma miejsce w przestrzeni publicznej, w darkroomie, łaźniach i zaułkach miejskich okolic. Okazało się, że seks bardzo silnie oraz dobitnie określa i kategoryzuje tożsamość mężczyzn homoseksualnych. Bywa także manifestem inności, wyrażonym wprost lub nie. Jako bezpośredni postulat wkracza na drogę queerową, jest dla gejów drogą do uwolnienia od heteronormy, do wyzwolenia i widoczności, wbrew uprzedzeniom i regułom społecznej kontroli. W fabułach seks gejów to także psychologiczna „gra” partnerów w negocjacje ról i rekonstrukcje męskości. Seksualność w analizach zdecydowanie potwierdziła swój status silnego i nierozerwalnego symbolicznego wyznacznika tożsamości każdego mężczyzny oraz jednego z najistotniejszych elementów społeczno-kulturowego procesu ich identyfikacji.

\section{Bibliografia}

Barthes R., Mitologie, przeł. A. Dziadek, Warszawa 2000.

Drabina A., Wizerunek mężczyzn homoseksualnych w serialu telewizyjnym. Serial Queer as Folk studium przypadku, niepublikowana praca licencjacka, 2013.

Drabina A., Wizerunki związków homoseksualnych mężczyzn w kulturze masowej. Studium wspótczesnej amerykańskiej kinematografii obyczajowej, niepublikowana praca magisterska, 2015. 
McNair B., Seks, demokratyzacja pożądania i media, czyli kultura obnażania, przeł. E. Klekot, Warszawa 2004.

Neary A., Same-sex relationship recognition and the weight of heteronormative expectation, „Socheolas" 4, 2012, nr 1.

Nowak S., Seksualny kapitał. Wyobrażone wspólnoty smaku i medialne tożsamości polskich gejów, Kraków 2013.

Peplau L.A., Research on homosexual couples: an overwiev, „Journal of Homosexuality” 8, 1982, nr 1.

Rose G., Interpretacja materiałów wizualnych. Krytyczna metodologia badań nad wizualnościa, przeł. E. Klekot, Warszawa 2010.

Sanders G.L., Men together: Working with gay couples in contemporary times, [w:] Couples on the Fault Line: New Directions for Therapists, red. P. Papp, Londyn-Nowy Jork 2000.

Seidman S., Społeczne tworzenie seksualności, przeł. P. Tomanek, Warszawa 2012.

Walters S.D., All The Rage: The Story of Gay Visibility in America, Chicago 2003.

Worth H., Reid A., McMillan K., Somewhere over the rainbow: love, trust and monogamy in gay relationships, „Journal of Sociology” 38, 2002, nr 3.

\section{Źródła audiowizualne}

August, reż. E. Rapaport, USA 2011.

Brokeback Mountain, reż. A. Lee, Kanada/USA 2005.

I Love You, Phillip Morris, reż. J. Requa, G. Ficcara, Francja/USA 2009.

Keep the Lights On, reż. I. Sachs, USA 2012.

The Living End, reż. G. Araki, USA 1992.

Longtime Companion, reż. N. René, USA 1989.

Love Is Strange, reż. I. Sachs, Francja/USA 2014.

Making love, reż. A. Hiller, USA 1982.

Parting Glances, reż. B. Sherwood, USA 1986.

Philadelphia, reż. J. Demme, USA 1993.

Queer as Folk, reż. S. DiMarco, J. Fawcett, USA 2000-2005.

Shelter, reż. J. Markowitz, USA 2007.

Trick, reż. J. Fall, USA 1999.

\section{Sex and masculinity in gay images in selected pop culture productions}

\section{Summary}

The article presents fragments of the results of the analysis of gay images in selected American dramas. The analysis was designed to read the symbols and signs of pop culture that define the relationship between the sexuality and the identity of homosexual men. The text is an attempt to understand and interpret the process of creation the meanings of the sex and gender categories in the popular culture space. It presents visuality as one of the most important dimensions of creating sexual imaginations, exposing intimacy and eroticism in the face of nonheteronormative sexual practices. This article aims to reconstruct fragments of the myth of gay identity in pop culture. 